\title{
Agency Costs of Free Cash Flow and Bidders' Long-run Takeover Performance
}

\author{
Lu Lin', Dan Lin ${ }^{2, *}$ \\ ${ }^{1}$ Department of Public Finance and Taxation, Takming University of Science and Technology, 11451, Taipei, Taiwan \\ ${ }^{2}$ Department of Banking and Finance, Takming University of Science and Technology, 11451, Taipei, Taiwan \\ *Corresponding author: mcylin@takming.edu.tw
}

Copyright (C) 2014 Horizon Research Publishing All rights reserved.

\begin{abstract}
This study investigates the relevance of Jensen's (1986) free cash flow theory to the market for corporate control in Australia. We introduce two proxies of free cash flow, excess cash holdings and excess accounting cash flow and test the relationship between the level of excess cash and bidders' long-run post-acquisition performance. Results indicate that the level of excess cash holdings does not provide a significant explanation for the cross-sectional variation in long-run post-acquisition performance. Results from the flow measure of cash indicate that the acquisitions carried out by bidders with excess accounting cash flow are not value-decreasing. This finding is contrary to the free cash flow hypothesis proposed by Jensen (1986).
\end{abstract}

Keywords Cash Holdings, Takeover, Acquisition, Long-run Performance, Free Cash Flow

\section{Introduction}

The agency costs of free cash flow hypothesis proposed by Jensen (1986) argues that when managers have more cash than is needed to fund all positive NPV projects (i.e., the free cash flow), there is an incentive for managers to waste the excess cash on unprofitable investments such as acquisitions. The objective of this study is to examine the impact of free cash flow on firms' corporate takeover decisions. Specifically, we test if acquisitions made by firms with high excess cash are value-decreasing; that is, whether the level of excess cash is negatively related to the long-run takeover performance of acquiring firms.

One contribution made by this study is that in addition to using the measure of excess cash holdings as in Harford's (1999) study, this paper includes a measure for the level of excess cash flow. In this study, the flow measure of cash is measured by the accounting cash flow, defined as the ratio of earnings after interest paid, tax paid and dividend paid but before depreciation to total assets. The latter measure is arguably closer to Jensen's definition of free cash flow than the measures used in previous studies.

The results show that the test of free cash flow hypothesis in the Australian takeover market is contrary to the predictions of the free cash flow theory. There is no evidence that the acquisitions carried out by excess accounting cash flow bidders are value-decreasing. Instead, bidders with higher excess accounting cash flow have better long-run post-acquisition performance.

This study continues as follows. In Section 2, we review the literature on the free cash flow hypothesis and the bidders' long-run takeover performance, and outline the hypotheses tested in this study. Data and methods are described in Section 3. In Section 4, we present the results from the test on the relationship between bidder long-run performance and the level of excess cash. Concluding remarks are offered in Section 5 .

\section{Literature Review and Hypotheses}

This section reviews the free cash flow hypothesis and its relation to the market for corporate control and provides several explanations that have been suggested to contribute to bidder long-run underperformance. The hypotheses tested are also discussed in this section.

\subsection{Free Cash Flow Hypothesis and Acquisitions}

Jensen (1986) suggests that in the presence of large free cash flow, the agency conflicts between managers and shareholders become more severe (that is, the free cash flow hypothesis). This is because retaining excess cash flow reduces the ongoing need for raising finance from the capital markets, thereby giving managers the freedom from capital providers' monitoring. From the shareholders' point of view, they would prefer this cash to be distributed back to them through dividends or share repurchase programs if firms have limited growth potential and the cash could not be better invested elsewhere.

Khan et al. (2012) find that firm leverage plays an important role in reducing the agency costs of free cash 
flow. Based on a sample of US firms over the period 1950-1994, Harford (1999) finds evidence supporting the free cash flow hypothesis. Cash rich acquirers have negative share-market returns at the takeover announcement period and the combined firms have poor operating performance. Schwetzler and Reimund(2004)who examine the cash holdings of German firms also find evidence consistent with the free cash flow hypothesis. They find that compared to a sample of firms matched on industry and firm size, firms with persistent excess corporate cash holdings over a three-year period have significantly lower operating performance, proxied by the operating cash flow.

In contrast, the study by Mikkelson and Partch(2002)finds evidence against the free cash flow theory. Specifically, they find that the operating performance of high cash firms is about 1.5 times higher than the performance of benchmark firms. They define high cash firms as firms that hold more than $25 \%$ of their total assets in cash and cash equivalents at the end of each fiscal year and whose cash ratios do not fall by more than one-third for the entire sample period.

The study by Gregory (2005) tests the free cash flow hypothesis by examining the long-run abnormal performance of UK acquirers. Gregory (2005) also finds evidence against Jensen's (1986) free cash flow hypothesis and that acquirers with high free cash flow outperform acquirers with low free cash flow. In addition, a positive relationship is reported between the cash flow and long-run performance of acquirers over a 60-month period. Wang (2010) finds a significantly positive relation between free cash flow and firm performance measures, inconsistent with the free cash flow hypothesis. A more recent paper by Gao (2011) examines the corporate cash reserves of bidders and their announcement returns and finds that bidders with high excess cash reserves operationally outperform bidders with low excess cash reserves.

\subsection{Bidder Long-run Takeover Performance}

Most studies on the long-run takeover performance document that bidders experience a significant negative drift in performance for up to five years after completion of the takeover. Agrawal, Jaffe, and Mandelker(1992), for example, report a statistically significant size and beta adjusted five-year cumulative average abnormal returns (CAARs) of $-10 \%$ to bidders. In the following, we discuss explanations that have been proposed to explain the long-run underperformance, including measurement issues, the performance extrapolation hypothesis, the method of payment hypothesis, and focused versus diversifying acquisitions.

Barber and Lyon (1997) identify three measurement errors associated with the two commonly used methods, CAR and BHAR, for testing long-run abnormal returns, including:

- New listing bias, which arises because newly listed firms that typically underperform an equally weighted market index are included in the benchmark but are excluded from the sample;
- Rebalancing bias, which arises because returns to the benchmark, such as an equally weighted market index, are often calculated with monthly rebalancing while the returns to sample firms are compounded without rebalancing; and

- Skewness bias, which arises because the distribution of abnormal returns is positively skewed.

In this study, we follow the method developed by Brown and da Silva Rosa (1998) to overcome the new listing bias and the problem of overstating traditional t-test statistics. The new listing bias is overcome by conditioning survival in the benchmark used. To test the significance of abnormal returns, a bootstrapping method is used to construct an empirical distribution of returns that solve the problem of overstating traditional t-test statistics.

The performance extrapolation hypothesis suggests that when assessing the value of an acquisition, the market often over-extrapolates the past performance of acquiring firms (Rau \& Vermaelen, 1998). Rau and Vermaelen(1998) find that glamour bidders (i.e., those with low book-to-market ratio) underperform value bidders (i.e., those with high book-to-market ratio). The former has three-year abnormal returns of $-17 \%$ while the latter has abnormal returns of $7 \%$.

Another explanation for the long-run underperformance is the method of payment hypothesis. The theory proposed by Myers and Majluf(1984) suggests that shares will be issued by firms only when they are overvalued. Accordingly, acquirers will prefer to offer shares if their equity is overvalued. Hence, the market will adjust the share price downwards in the long-run to its "intrinsic" value if shares are used as the medium of payment. Loughran and Vijh(1997) document that acquirers who make share offers earn $24 \%$ less than control firms while acquirers who make cash offers earn $18 \%$ more than control firms.

Previous studies also find that acquirers' long-run takeover performance is related to the mode of acquisition (Loughran \&Vijh, 1997). Martin (1996) shows that the method of payment is partly related to the mode of acquisition where mergers tend to be financed by stock while tender offers are often financed by cash. Thus, this study uses the method of payment dummy variable to capture the mode of acquisition effect. Previous studies have found that diversifying acquisitions are beneficial for acquirer's management but not for their shareholders, leading to long-run underperformance [e.g., Amihud and Lev (1981); Morck, Shleifer and Vishny(1990)]. Jensen (1988) argues that managers with unused borrowing power and large free cash flows are more likely to undertake value-decreasing diversifying acquisitions. Using a four-digit SIC code to measure the degree of diversification, Agrawal et al. (1992) find that conglomerate mergers outperform non-conglomerate mergers.

Based on the above discussion, this study tests if firms with substantial free cash flow, measured by excess cash holdings and excess accounting cash flow, are more likely to invest in negative NPV projects by examining bidders' abnormal returns. That is, the following hypotheses are 
tested:

- H1: The level of excess cash holdings is negatively associated with the long-run post-acquisition performance of bidders.

- H2: The level of excess accounting cash flow is negatively associated with the long-run post-acquisition performance of bidders.

\section{Data and Methods}

\subsection{Data}

The takeover data are obtained from the SDC Platinum database between fiscal years 1993 to 2000 . The accounting data are obtained from the Aspect Financial database, and the monthly share return data used to calculate prior share-market performance are collected from the Share Price $\&$ Price Relative Database (SPPR).To test the relationship between long-run post-acquisition performance and the level of excess cash, our sample is limited to "completed" takeovers between fiscal years 1993 and 2000. After excluding firms with missing data, the final sample includes 556 acquiring firms.

\subsection{Methods}

To test the effect of free cash flow, measured by excess cash, on long-run post-acquisition returns to bidders, the following two models are tested:

$$
\begin{aligned}
& \text { BHAR }_{\mathrm{it}}=\alpha_{\mathrm{i}}+\beta^{\prime}{ }_{\mathrm{t}} \text { Excash }+\delta^{\prime}{ }_{\mathrm{t}} \mathrm{X}_{\mathrm{t}-1}+\mathrm{u}_{\mathrm{t}} \\
& \mathrm{BHAR}_{\mathrm{it}}=\alpha_{\mathrm{i}}+\beta^{\prime}{ }_{\mathrm{t}} \mathrm{Exacccf}+\delta^{\prime}{ }_{\mathrm{t}} \mathrm{X}_{\mathrm{t}-1}+\mathrm{u}_{\mathrm{t}}
\end{aligned}
$$

where $B H A R_{i t}$ is the buy-and-hold abnormal return, measured as the buy-and-hold return to sample firms less the buy-and-hold return to the market portfolio. This study follows Brown and da Silva Rosa's (1998) method of calculating the long-run abnormal returns. Two proxies for the market portfolio are used; one is the size decile return and the other is the market return. In other words, bidder long-run takeover performance is measured by EDEAR (equal weighted decile adjusted return) or EMKAR (equal weighted market adjusted return) over the event window $[+1,+36]$ defined in months relative to the first takeover announcement. To counter the skewness bias in BHAR that has been noted by Lyon et al. (1999), this study constructs an empirical distribution of returns from 1,001 control portfolios as modelled by Brown and da Silva Rosa (1998) to determine the significance of abnormal returns. $\alpha_{i}$ is a constant. Excash and Exacccfare the two measures of excess cash, that is, excess cash holdings and excess accounting cash flow, respectively. Excess cash holdings and excess accounting cash flow, represent a stock measure and a flow measure, respectively. The stock measure was used in Harford's (1999) study and the flow measure was adopted by Opler et al. (1999). To obtain the level of excess cash, the normal cash levels are estimated first. Table 1 shows the specifications of the cash normal model. Following Harford's (1999) approach, sample firms are grouped by industry sectors. Excess cash is defined as the difference between the firm's cash holdings (or accounting cash flow, defined as the ratio of earnings after interest paid, tax paid and dividend paid but before depreciation to total assets) and the average value predicted for its industry, measured at the end of year $\mathrm{t}-1$. The later value is estimated using a cash normal model. $X_{t-1}$ is a set of control variables, which are included in the light of empirical precedent and are discussed below. $u_{t}$ is the error term assumed to be normally distributed with zero mean and constant variance.

\begin{tabular}{|c|c|c|}
\hline Variables & Model 1 & Model 2 \\
\hline Dependent & CASHit & ACCCFit \\
\hline \multirow[t]{13}{*}{ Independent } & TD_ait & TD_ait \\
\hline & Capex_ait & Capex_ait \\
\hline & NWC_ait & NWC_ait \\
\hline & SIZEit & SIZEit \\
\hline & MV/BVit & MV/BVit \\
\hline & VARCASHit & VARACCCFit \\
\hline & YD93 & YD93 \\
\hline & YD94 & YD94 \\
\hline & YD95 & YD95 \\
\hline & YD96 & YD96 \\
\hline & YD97 & YD97 \\
\hline & YD98 & YD98 \\
\hline & YD99 & YD99 \\
\hline
\end{tabular}

Table 1. Specification of the cash normal model

CASH is the cash holdings, defined as the ratio of cash and short-term deposits deflated by total assets. ACCCF is the accounting cash flow, defined as the ratio of earnings after interest paid, tax paid and dividend paid but before depreciation to total assets. TD_a is the ratio of total debt to total assets. Capex_a is the ratio of capital expenditures to total assets. NWC_a is the ratio of net working capital excluding cash to total assets. SIZE is the natural $\log$ of total assets in 1990 prices. MV/BV is the ratio of book value of total assets minus the book value of equity plus the market value of equity to book value of assets. VARCASH (or VARACCCF) is calculated as the difference between the max and min values of CASH (or ACCCF) divided by the mean over a six year period which includes two years prior to and three years after the sample year plus the sample year itself. YD refers to year dummies.

The control variables are as follows. SIZE is measured as the natural log of total assets in constant 1990 prices. The consumer price index serves as the deflator. FOCUS is equal to one if both the target and the acquirer have the same two-digit SIC code and zero otherwise. DUMMOP is an indicator and is equal to one if the bidder uses cash only in financing the acquisition and zero otherwise. BV/MV is defined as the ratio of book value of total assets to book value of total assets minus the book value of equity plus the 
market value of equity, measured at the financial year before the year of takeover. MULTI is a dummy variable and is equal to one if the acquirer is involved in more than one takeover in the acquisition year and zero otherwise. This variable is included because some acquirers may be involved in multiple acquisitions, which may have an impact on their share returns, as suggested by Antoniou and Zhao (2004).

\section{Results and Discussion}

The univariate statistics for the sample of 556 acquiring firms are presented in Table 2. Panel A shows that the average excess cash holdings of acquiring firms is negative $(-0.054)$, which suggests that acquiring firms on average do not have excess cash holdings. Panel B presents the long-run post-acquisition returns to bidders. The significance of abnormal returns is indicated by the number of the control portfolios with a higher mean return than the average return to sample firms, as shown in the last column of Table 2. The Panel shows that 469 of the 1,001 control portfolios have achieved a higher mean (equal weighted) size decile adjusted return than the average return of $-3.9 \%$ to sample acquiring firms, and that 515 of the 1,001 control portfolios display a higher mean value weighted decile adjusted return than the average return of $-3 \%$ to sample firms. The results suggest that acquiring firms' long-run performance is not significantly different from control firms.

Table 2. Summary statistics of sample acquiring firms

\begin{tabular}{|c|c|c|c|c|c|c|}
\hline & Mean & Med & Min & $\operatorname{Max}$ & SD & $\begin{array}{c}\text { No. control portfolios with higher } \\
\text { mean return }\end{array}$ \\
\hline \multicolumn{7}{|l|}{ Panel A: Financial characteristics } \\
\hline Excash & -0.05 & -0.07 & -0.65 & 0.86 & 0.20 & \\
\hline Exacccf & 0.04 & 0.03 & -1.22 & 1.79 & 0.19 & \\
\hline SIZE & 13.73 & 13.49 & 8.30 & 19.91 & 2.31 & \\
\hline $\mathrm{BV} / \mathrm{MV}$ & 0.84 & 0.78 & 0.01 & 4.95 & 0.49 & \\
\hline \multicolumn{7}{|c|}{ Panel B: Long-run post-acquisition performance } \\
\hline Size decile adjusted return & -0.04 & -0.25 & -1.78 & 7.37 & 0.97 & 469 \\
\hline Value weighted decile adjusted return & -0.03 & -0.24 & -1.75 & 7.42 & 0.97 & 515 \\
\hline Equal weighted market adjusted return & -0.09 & -0.31 & -1.77 & 7.39 & 0.97 & 331 \\
\hline \multirow[t]{2}{*}{ Value weighted market adjusted return } & -0.03 & -0.23 & -1.22 & 7.50 & 0.98 & 417 \\
\hline & $\begin{array}{l}\text { No. of } \\
\text { bidder }\end{array}$ & $\%$ & & & & \\
\hline \multicolumn{7}{|c|}{ Panel C: Focused vs. diversifying acquisition } \\
\hline Focused acquisition & 270 & 48.6 & & & & \\
\hline Diversification & 286 & 51.4 & & & & \\
\hline Total & 556 & & & & & \\
\hline \multicolumn{7}{|l|}{ Panel D: Method of payment } \\
\hline Cash & 388 & 69.8 & & & & \\
\hline Common stock & 83 & 14.9 & & & & \\
\hline Hybrid & 85 & 15.3 & & & & \\
\hline Total & 556 & & & & & \\
\hline \multicolumn{7}{|l|}{ Panel E: Single vs. multiple acquirers } \\
\hline Multiple acquirer & 144 & 25.9 & & & & \\
\hline Single acquirer & 412 & 74.1 & & & & \\
\hline Total & 556 & & & & & \\
\hline
\end{tabular}

Excash (or Exacccf) is defined as the difference between the firm's ratio of cash holdings (or accounting cash flow) to total assets and the average value predicted for its industry. SIZE is measured as the natural log of total assets in 1990 prices. BV/MV is defined as the ratio of book value of assets to book value of total assets minus the book value of equity plus the market value of equity. 
Table 3 presents the summary statistics and Wilcoxon rank-sum test for bidders with positive versus negative excess cash. Based on the definition of excess cash holdings, bidders with positive excess cash holdings have significantly smaller firm size than bidders with negative excess cash holdings. This finding is consistent with the argument that smaller bidders tend to suffer more severe information asymmetries and have more financial constraints. Panel B shows that bidders with positive accounting cash flow are significantly larger than bidders with negative accounting cash flow. The results suggest that firm size is negatively correlated with cash holdings but positively correlated with cash flow, which is also evidence in studies by Kim et al. (1998) and Pinkowitz(1998).

Table 3 presents the summary statistics and Wilcoxon rank-sum test for bidders with positive versus negative excess cash. Based on the definition of excess cash holdings, bidders with positive excess cash holdings have significantly smaller firm size than bidders with negative excess cash holdings. This finding is consistent with the argument that smaller bidders tend to suffer more severe information asymmetries and have more financial constraints. Panel B shows that bidders with positive accounting cash flow are significantly larger than bidders with negative accounting cash flow. The results suggest that firm size is negatively correlated with cash holdings but positively correlated with cash flow, which is also evidence in studies by Kim et al. (1998) and Pinkowitz(1998).

Moreover, the comparison of three-year post-acquisition performance of bidders with positive excess cash and bidders with negative excess cash shows some interesting results. On the one hand, no significant differences in long-run post-acquisition performance are found between bidders with positive and negative excess cash holdings. On the other hand, when the level of excess cash is based on the definition of accounting cash flow, bidders with positive excess cash show significantly better long-run performance than bidders with negative excess cash for all four measures of long-run performance. This finding is contrary to the prediction of Jensen's (1986) free cash flow hypothesis, which suggests that firms with more free cash flow are likely to make value-decreasing acquisitions that eventually lead to poor long-run post-acquisition performance. Although this result is inconsistent with Jensen's (1986) theory, it is possible that firms with high free cash flow have superior long-run performance. This is because a high level of free cash flow implies that these firms have been performing well and have superior management who are more likely to undertake value-enhancing rather than value-decreasing acquisitions, and therefore have better long-run performance.
The impact of excess cash together with other explanatory variables on acquirers' long-run post-acquisition buy-and-hold returns is examined using an ordinary least square regression as shown in Table 4. Models 1 and 3 of Table 4 use equal weighted decile adjusted returns as the dependent variable while Models 2 and 4 use equal weighted market adjusted returns as the dependent variable.

Models 1 and 2 of Table 4 show that the coefficients of excess cash holdings have the expected negative sign but are not statistically significant. The result thus provides weak support for the free cash flow hypothesis. Firm size is positively related to bidders' long-run performance. This suggests that larger acquiring firms perform better in the long-run. The coefficient of the dummy variable for focused acquisitions is not statistically significant either. This is contrary to the results found by Harford (1999) who documents that cash rich acquirers are more likely to make diversifying investments. In Models 3 and 4, the level of excess cash is measured by accounting cash flow, Exacccf. Consistent with the univariate test results, bidders with positive excess accounting cash flow significantly outperform bidders with negative excess accounting cash flow in the long-run. This finding is inconsistent with the free cash flow hypothesis that firms with a higher level of excess cash tend to make value-decreasing acquisitions. The positive relationship between excess accounting cash flow and the long-run post-acquisition performance can be interpreted as that acquisitions provide managers a means to use up excess cash flows, and this is likely to increase the indebtedness of the acquiring firm. The strengthened relationship between managers and bondholders means that managers have less potential to waste free cash flow and this in turn leads to better returns to bidders in the long-run. Another explanation consistent with these results is that firms with positive excess accounting cash flow are firms that have been well managed and their managers are more likely to carry out value-increasing acquisitions. In addition, Model 4 shows that acquisitions financed by cash are related to better bidders' long-run performance. The result provides support for our prior argument that acquisitions provide a means for managers to use up excess cash flow for the benefit of shareholders.

Overall, the evidence from bidders with excess accounting cash flow shows that the higher the level of excess accounting cash flow, the better the long-run performance, contrary to Jensen's (1986) free cash flow hypothesis. This result is, however, consistent with Gregory's (2005) finding that high free cash flow acquirers have better long-run performance based on a sample of UK acquirers between 1984 and 1992. 
Table 3. Summary statistics for bidders with positive and negative excess cash

\begin{tabular}{|c|c|c|c|c|c|c|c|c|}
\hline \multirow{3}{*}{$\begin{array}{c}\text { Panel A: Excash } \\
\text { Excash }\end{array}$} & \multicolumn{3}{|c|}{ Bidders with +veExcash } & \multicolumn{3}{|c|}{ Bidders with -veExcash } & \multirow{2}{*}{\multicolumn{2}{|c|}{$\begin{array}{l}\mathrm{Z} \text { test for diff. in } \\
\text { median values }\end{array}$}} \\
\hline & \multirow{2}{*}{$\begin{array}{l}\text { Mean } \\
0.183\end{array}$} & \multirow{2}{*}{$\begin{array}{c}\text { Median } \\
0.100\end{array}$} & \multirow{2}{*}{$\begin{array}{c}\text { Std. Dev } \\
0.202\end{array}$} & \multirow{2}{*}{$\begin{array}{l}\text { Mean } \\
-0.131\end{array}$} & \multirow{2}{*}{$\begin{array}{l}\text { Median } \\
-0.094\end{array}$} & \multirow{2}{*}{$\begin{array}{c}\text { Std. Dev } \\
0.130\end{array}$} & & \\
\hline & & & & & & & 17.540 & $* * *$ \\
\hline & & & & & & & $(0.000)$ & \\
\hline Exacccf & 0.002 & 0.009 & 0.283 & 0.049 & 0.040 & 0.141 & -3.648 & $* * *$ \\
\hline & & & & & & & $(0.000)$ & \\
\hline SIZE & 12.781 & 12.388 & 2.295 & 14.043 & 13.912 & 2.231 & -5.684 & $* * *$ \\
\hline & & & & & & & $(0.000)$ & \\
\hline $\mathrm{BV} / \mathrm{MV}$ & 0.785 & 0.726 & 0.508 & 0.862 & 0.800 & 0.480 & -2.807 & $* * *$ \\
\hline & & & & & & & $(0.005)$ & \\
\hline EDEAR & 0.044 & -0.298 & 1.251 & -0.066 & -0.226 & 0.860 & -0.672 & \\
\hline & & & & & & & $(0.502)$ & \\
\hline VDEAR & 0.058 & -0.282 & 1.253 & -0.059 & -0.212 & 0.862 & -0.507 & \\
\hline & & & & & & & $(0.612)$ & \\
\hline EMKAR & 0.004 & -0.337 & 1.272 & -0.119 & -0.302 & 0.856 & -0.570 & \\
\hline & & & & & & & $(0.569)$ & \\
\hline VMKAR & 0.058 & -0.273 & 1.284 & -0.060 & -0.219 & 0.853 & -0.623 & \\
\hline & & & & & & & $(0.533)$ & \\
\hline No. of firms & 136 & & & 420 & & & & \\
\hline \multirow[t]{2}{*}{ Panel B: Exaccef } & \multicolumn{3}{|c|}{ Bidders with +veExaccef } & \multicolumn{3}{|c|}{ Bidders with -veExaccef } & \multirow{2}{*}{\multicolumn{2}{|c|}{$\begin{array}{l}\mathrm{Z} \text { test for diff. in } \\
\text { median values }\end{array}$}} \\
\hline & Mean & Median & Std. Dev & Mean & Median & Std. Dev & & \\
\hline \multirow[t]{2}{*}{ Exacccf } & 0.104 & 0.069 & 0.139 & -0.114 & -0.045 & 0.193 & 18.800 & $* * *$ \\
\hline & & & & & & & $(0.000)$ & \\
\hline \multirow[t]{2}{*}{ Excash } & -0.075 & -0.074 & 0.170 & -0.006 & -0.052 & 0.255 & -3.319 & $* * *$ \\
\hline & & & & & & & $(0.001)$ & \\
\hline \multirow[t]{2}{*}{ SIZE } & 14.112 & 13.967 & 2.031 & 12.877 & 12.345 & 2.656 & 6.254 & $* \star * *$ \\
\hline & & & & & & & $(0.000)$ & \\
\hline \multirow[t]{2}{*}{$\mathrm{BV} / \mathrm{MV}$} & 0.802 & 0.751 & 0.442 & 0.9363 & 0.863 & 0.567 & -3.039 & $* * *$ \\
\hline & & & & & & & $(0.002)$ & \\
\hline \multirow[t]{2}{*}{ EDEAR } & -0.029 & -0.206 & 0.849 & -0.064 & -0.315 & 1.201 & 2.253 & $* *$ \\
\hline & & & & & & & $(0.024)$ & \\
\hline \multirow[t]{2}{*}{ VDEAR } & -0.020 & -0.199 & 0.852 & -0.053 & -0.318 & 1.204 & 2.189 & $* *$ \\
\hline & & & & & & & $(0.029)$ & \\
\hline \multirow[t]{2}{*}{ EMKAR } & -0.078 & -0.254 & 0.851 & -0.108 & -0.411 & 1.213 & 2.334 & $* *$ \\
\hline & & & & & & & $(0.020)$ & \\
\hline \multirow[t]{2}{*}{ VMKAR } & -0.022 & -0.189 & 0.853 & -0.042 & -0.308 & 1.212 & 2.255 & ** \\
\hline & & & & & & & $(0.024)$ & \\
\hline No. of firms & 386 & & & 170 & & & & \\
\hline
\end{tabular}

Excash(or Exacccf) is defined as the difference between the firm's ratio of cash holdings (or accounting cash flow) to total assets and the average value predicted for its industry. SIZE is measured as the natural log of total assets in 1990 prices. BV/MV is defined as the ratio of book value of assets to book value of total assets minus the book value of equity plus the market value of equity. EDEAR is the equal weighted decile adjusted return; VDEAR is the value weighted decile adjusted return; EMKAR is the equal weighted market adjusted return; VMKAR is the value weighted market adjusted return. Numbers in parentheses are p-values. $* * *$ denotes significance at the $1 \%$ level, 2 tail test; ** denotes significance at the $5 \%$ level, 2 tail test; * denotes significance at the $10 \%$ level, 2 tail test. 
Table 4. Multivariate regressions of bidder long-run takeover performance

\begin{tabular}{|c|c|c|c|c|c|c|c|c|}
\hline & Model 1 & & Model 2 & & Model 3 & & Model 4 & \\
\hline \multirow[t]{2}{*}{ Constant } & -0.923 & $* * *$ & -0.943 & $* * *$ & -0.856 & $* * *$ & -0.309 & $* * *$ \\
\hline & $(-4.947)$ & & $(-4.910)$ & & $(-4.598)$ & & $(-3.619)$ & \\
\hline \multirow[t]{2}{*}{ Excash } & -0.018 & & -0.018 & & & & & \\
\hline & $(-0.118)$ & & $(-0.112)$ & & & & & \\
\hline \multirow[t]{2}{*}{ Exacccf } & & & & & 0.285 & & 0.387 & $* *$ \\
\hline & & & & & (1.531) & & $(2.400)$ & \\
\hline \multirow[t]{2}{*}{ SIZE } & 0.052 & $* * *$ & 0.049 & $* * *$ & 0.046 & $* * *$ & & \\
\hline & (3.969) & & (3.605) & & (3.578) & & & \\
\hline \multirow[t]{2}{*}{$\mathrm{BV} / \mathrm{MV}$} & 0.023 & & 0.061 & & 0.028 & & 0.061 & \\
\hline & $(0.414)$ & & $(0.849)$ & & $(0.492)$ & & $(0.847)$ & \\
\hline \multirow[t]{2}{*}{ FOCUS } & -0.007 & & -0.035 & & -0.026 & & -0.073 & \\
\hline & $(-0.114)$ & & $(-0.556)$ & & $(-0.442)$ & & $(-1.147)$ & \\
\hline \multirow[t]{2}{*}{ DUMMOP } & 0.084 & & 0.106 & & 0.086 & & 0.154 & $* *$ \\
\hline & (1.288) & & (1.557) & & (1.327) & & $(2.280)$ & \\
\hline \multirow[t]{2}{*}{ MULTI } & -0.050 & & -0.064 & & -0.052 & & -0.026 & \\
\hline & $(-0.754)$ & & $(-0.903)$ & & $(-0.780)$ & & $(-0.378)$ & \\
\hline Adj $R^{2}$ & 0.027 & & 0.023 & & 0.033 & & 0.012 & \\
\hline F-statistic & 3.49 & $* * *$ & 3.16 & $* * *$ & 4.04 & & 2.34 & \\
\hline P-value & 0.002 & & 0.005 & & 0.001 & & 0.04 & \\
\hline
\end{tabular}

Excash (or Exacccf) is defined as the difference between the firm's ratio of cash holdings (or accounting cash flow) to total assets and the average value predicted for its industry. SIZE is measured as the natural log of total assets in 1990 prices. BV/MV is defined as the ratio of book value of assets to book value of total assets minus the book value of equity plus the market value of equity. FOCUS is equal to one if both the target and the acquirer have the same two-digit SIC code and zero otherwise. DUMMOP is an indicator and is equal to one if the bidder uses cash to finance the acquisition and zero otherwise. MULTI is a dummy variable and is equal to one if the acquirer is involved in multiple takeovers in the acquisition year and zero otherwise. The T-stats are in parentheses. Significance is based on White-adjusted standard errors. *** denotes significance at the $1 \%$ level; ** denotes significance at the $5 \%$ level; * denotes significance at the $10 \%$ level.

\section{Conclusion}

This study investigates the intersection of two areas of the literature, the level of excess cash and acquisitions. In this study, we examine whether the level of excess cash has any impact on bidders' long-run post-acquisition performance. Because high levels of excess cash can be used by managers to carry out acquisitions at their discretion, we incorporate excess cash holdings and excess accounting cash flow in the long-run analysis of acquirers' share-market performance to test whether the cash and cash flow hoarding behaviour of Australian firms is value-enhancing or value-decreasing from shareholders' view point.

The results show that bidders with positive excess cash holdings have better growth opportunities and that larger firms and cash financed acquisitions are associated with better long-run post-acquisition returns to bidders. As for the results when excess accounting cash flow is used to measure excess cash, bidders with positive excess accounting cash flow have significantly better long-run performance than bidders with negative excess accounting cash flow, contrary to the prediction of Jensen's (1986) free cash flow theory. This finding suggests that acquisitions provide managers a means to use up excess cash flow so that they have less potential to waste the free cash flow.

In conclusion, this study tests the free cash flow hypothesis in a takeover context and do not find evidence supporting the hypothesis. The contribution made by this study is that we have adopted two proxies for free cash flow, a cash holding measure and a cash flow measure. This enables us to provide a stronger and more robust test of the free cash flow hypothesis.

\section{REFERENCES}

[1] A. Agrawal, J. F. Jaffe, G. N. Mandelker. 1992. The post-merger performance of acquiring firms: A re-examination of an anomaly, Journal of Finance, Vol. 47, 
1605-1621.

[2] Y. Amihud, B. Lev. 1981. Risk reduction as a managerial motive for conglomerate mergers, Bell Journal of Economics, Vol. 12, 605-617.

[3] A. Antoniou, H. Zhao. 2004. Long-run post takeover stock return: The impact of overlapping return, takeover premium, and method of payment, Working paper, University of Durham.

[4] B. M. Barber, J. D. Lyon. 1997. Detecting long-run abnormal stock returns: The empirical power and specification of test statistics, Journal of Financial Economics, Vol. 43, 341-372.

[5] P. Brown, R. da Silva Rosa. 1998. Research method and the long-run performance of acquiring firms, Australian Journal of Management, Vol. 23, 23-38.

[6] N. Gao. 2011. The adverse selection effect of corporate cash reserve: Evidence from acquisitions solely financed by stock, Journal of Corporate Finance, Vol. 17, 789-808.

[7] A. Gregory. 2005. The long run abnormal performance of UK acquirers and the free cash flow hypothesis, Journal of Business Finance and Accounting, Vol. 32, 777-814.

[8] J. Harford. 1999. Corporate cash reserves and acquisitions, Journal of Finance, Vol. 54, 1969-1997.

[9] M. C. Jensen. 1986. Agency costs of free cash flow, corporate finance, and takeovers, American Economic Review, Vol. 76, 323-329.

[10] M. C. Jensen. 1988. The takeover controversy: Analysis and evidence. In: Coffee JC, Lowenstein L \& Rose-Ackerman S (eds.) Knights, raiders, and targets: The impact of the hostile takeover, Oxford University Press, New York, 314-354.

[11] A. Khan, A.Kaleem, M. S.Nazir. 2012. Impact of financial leverage on agency cost of free cash flow: Evidence from the manufacturing sector of Pakistan, Journal of Basic and Applied Scientific Research, Vol. 2, 6694-6700.

[12] C. S. Kim, D. C.Mauer, A. E. Sherman. 1998. The determinants of corporate liquidity: Theory and evidence, Journal of Financial and Quantitative Analysis, Vol. 33, 335-359.
[13] T. Loughran, A. M. Vijh. 1997. Do long-term shareholders benefit from corporate acquisitions? Journal of Finance, Vol. $52,1765-1790$.

[14] J. D. Lyon, B. M. Barber, C. Tsai. 1999. Improved methods for tests of long-run abnormal stock returns, Journal of Finance, Vol. 54, 165-201.

[15] K. J. Martin. 1996. The method of payment in corporate acquisitions, investment opportunities, and management ownership, Journal of Finance, Vol. 51, 1227-1246.

[16] W. H. Mikkelson, M. M.Partch. 2002. Do persistent large cash reserves hinder performance? Working paper, University of Oregon.

[17] R. Morck, A.Shleifer, R. W. Vishny. 1990. Do managerial objectives drive bad acquisitions? Journal of Finance, Vol. 45, 31-48.

[18] S. C. Myers, N. S.Majluf. 1984. Corporate financing and investment decisions when firms have information that investors do not have, Journal of Financial Economics, Vol. $13,187-221$.

[19] T. Opler, L. Pinkowitz, R. Stulz, R. Williamson. 1999. The determinants and implications of corporate cash holdings, Journal of Financial Economics, Vol. 52, 3-46.

[20] L. Pinkowitz. 1998. The market for corporate control and corporate cash holdings, Working paper, Georgetown University.

[21] P. R. Rau, T.Vermaelen. 1998. Glamour, value and the post-acquisition performance of acquiring firms, Journal of Financial Economics, Vol. 49, 223-253.

[22] B. Schwetzler, C.Reimund. 2004. Valuation effects of corporate cash holdings: Evidence from Germany, Working paper, Leipzig Graduate School of Management.

[23] G. Wang. 2010. The impacts of free cash flows and agency costs on firm performance, Journal of Service Science and Management, Vol. 3, 408-418. 